\title{
Historical Ecology and 600 Years of Fish Use on Atafu Atoll, Tokelau
}

\author{
Rintaro Ono, School of Marine Science and Technology, Department of Maritime \\ Civilization, Tokai University, Japan \\ David J. Addison, Samoan Studies Institute, American Samoa Community College
}

\section{Introduction}

A NZ dependency, Tokelau is a group of three atolls as including Fakaofo, Nukunonu and Atafu, which located around $500-600 \mathrm{~km}$ north of Samoa at a latitude of S8-10 and longitude of W171$173^{\circ}$ (Figure 1). Marine exploitation, especially fishing, is the most important subsistence activity in Tokelau and has multifarious cultural implications (e.g., Hooper 1985, 1991, 2008, 2010; Huntsman and Hooper 1996; Mafutaga a Toeaina o Atafu i Matauala Porirua 2008; Matagi Tokelau 1991; Ono and Addison 2009). For instance, the Mafutaga a Toeaina o Atafu i Matauala Porirua (2008) report Atafu's rich traditions of fishing lore and a total of 108 fishing methods on Atafu Atoll, one of the atolls in Tokelau. Our recent ethno-ecological study on Atafu also confirms active marine use by the islanders and collected over 160 fish names and 12 mollusc names (see Ono and Addison 2009: Appendix 1). The classification and diversity of fish and mollusc names on Atafu clearly show the overwhelming importance of fish resources, as opposed to molluscs.

An analysis of fish name classification also enables us to consider people's preferences regarding fish and other marine resources. Also, the variety and character of fishing methods and fish name classification on Atafu reveal that there are more variations in names and fishing methods for larger pelagic fish species, such as those in the families Carangidae and Scombridae, and show a high dependence on outer-reef and offshore resources. Such tendencies possibly indicate that outer-reef and offshore resources were significant both economically and culturally in the past on Atafu as well.

In terms of prehistoric fishing, however, a previous archaeological study on Atafu and Fakaofo by Best (1988) and zoo-archaeological analysis of fish remains from Fakaofo by McAlister (2002) report absent or a very limited number of tunas (Scombridae) among the assemblage. A possible reason for the near absence of tunas in their studies might be because of their limited scope of analysis; for their identifications they did not analyse vertebra, which are one of the most diagnostic and solid parts of tuna skeletons (e.g., Davidson et al. 1999; Leach et al. 1997; Ono 2003, 2004, 2010; Ono and Intoh 2011). Alternatively, it is also possible that tunas and other 
pelagic fish were not the major marine resource exploited in prehistoric times on Fakaofo. In any case, since McAlister's study has been the only analysis of archaeological fish remains from Tokelau, it is impossible to say whether the much higher dependence on reef and lagoon fish resources prehistorically on Fakaofo is replicated at other location in Tokelau for the prehistoric period.

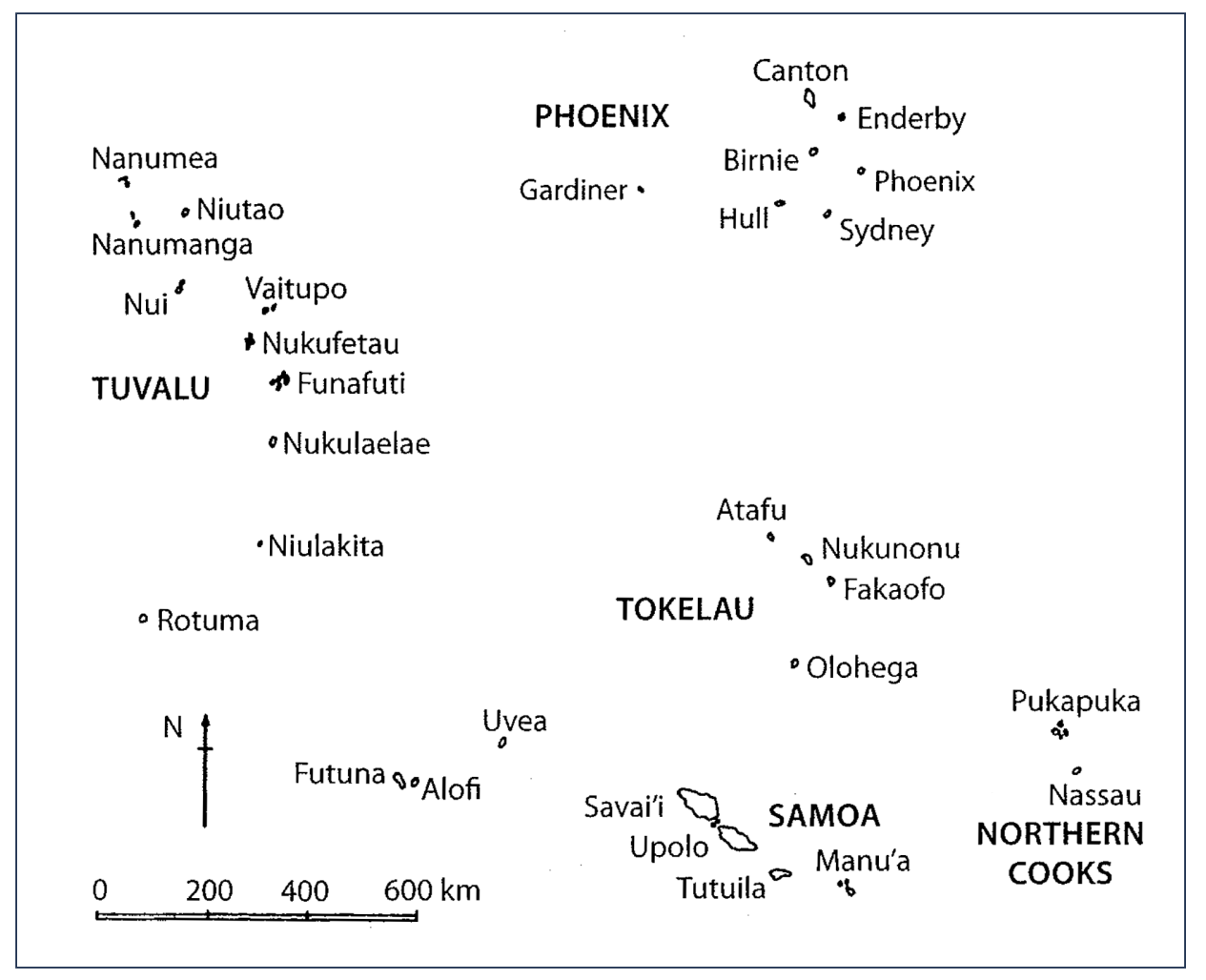

Figure 1. Tokelau and its location.

Source: Matagi Tokelau. 1991. Matagi Tokelau: History and traditions of Tokelau. Apia (Samoa) and Suva (Fiji): Office of Tokelau Affairs and the Institute of Pacific Studies, University of the South Pacific.

To improve such archaeological limits of prehistoric fishing data in Tokelau, we conducted excavations on Atafu in 2008 and 2009. We have included vertebra for identification of fish species in analysing our excavated fish remains. In this paper, we first discuss Tokelau fishing lore, focusing on fishing practices and technologies as well as materials and the conservational aspect of fishing on Atafu. Secondly, we examine prehistoric fish use and fishing strategies on Atafu based on our recent excavations. At the final stage of this paper, we try to combine both ethnoecological and archaeological data to discuss $600+$ years of fish use on Atafu from a historical ecology perspective.

\section{Geo-Ecological Background of Tokelau}

Among the three atolls in Tokelau, Atafu is located at the north-west end of the archipelago, with Nukunonu in the middle and Fakaofo to the south-east. Besides these three atolls, another atoll named Olohega is located at the south end of the archipelago. Olohega (or Swains Island) is politically a part of the U.S. Territory of American Samoa and is situated $160 \mathrm{~km}$ to the south of the other three atolls at $S 11^{\circ}$ and $\mathrm{W} 171^{\circ}$.

The total land area of Tokelau is tiny; the combined dry land area of all three atolls (excluding Olohega) comprises only $12.2 \mathrm{~km}^{2}$ of dry land (Huntsman and Hooper 1996). Tokelau's exclusive economic zone is considerably larger, covering some $290,000 \mathrm{~km}^{2}$ of ocean (Passfield 1998:2). The 
average mean annual temperature in Tokelau is $28^{\circ} \mathrm{C}$, and the annual rainfall is $2900 \mathrm{~mm}$ (Toloa et al. 1994). Geoculturally, Tokelau is located at a crossroads between East and West Polynesia (Burrows 1939), about $400 \mathrm{~km}$ east of Tuvalu and $400 \mathrm{~km}$ west of the Northern Cook Islands.

As is the case with most low and exposed atolls, Tokelau is particularly susceptible to wave surge during tropical storms. Between November and March, the weather is often unsettled, and the atolls are exposed to high winds and rough seas. During these months, sea travel is frequently restricted to the sheltered waters inside the reef (Matagi Tokelau 1991:6). Occasionally, the atolls are struck by cyclones during this stormy season.

Geologically, Atafu, Nukunonu, and Fakaofo are typical atolls with a large central lagoon surrounded by an intermittent chain of sandy islets known as motu; Olohega has a landlocked brackish water lake in the centre instead of a central lagoon. The largest of the atolls is Nukunonu, with a land area of about $5.5 \mathrm{~km}^{2}$, the second largest is Fakaofo with $3 \mathrm{~km}^{2}$, and Atafu is the smallest with $2.5 \mathrm{~km}^{2}$, while the land area of Olohega is about $1.5 \mathrm{~km}^{2}$. Lagoon size is even more variable between atolls: Atafu's lagoon is considerably smaller than the other two, covering only $19 \mathrm{~km}^{2}$, compared to $109 \mathrm{~km}^{2}$ for Nukunonu and $59 \mathrm{~km}^{2}$ for Fakaofo (Huntsman and Hooper 1996).

Most of the motus of Tokelau's atolls are covered with dense groves of coconut palms except some areas where littoral forest dominates. The most common terrestrial plant species are Cordia subcordata, Guettarda speciosa, Hernandia nymphaeifolia, and Pisonia grandis, while Pandanus tectorius and Tournefortia argentea prevail on the margins of the littoral forest (Whistler 1988). The main food plants are mostly root crops (pulaka or Cyrtosperma chamissonis and taamu or Alocasia macrorrhizos.) and fruit trees (screwpine - Pandanus tectorius, breadfruit - Artocarpus altilis, bananas - Musa spp., coconut - Cocos nucifera, and papaya Carica papaya). Pulaka is cultivated in swampy pits excavated in the centre of some sandy motus where the Ghyben-Herzberg fresh-water lens is close to the surface, while fruits trees are planted both around houses in the village and on motus.

Every island except Olohega has a large inner lagoon with a variety of fish and mollusc species. The major fish habitats in the lagoons support species of Holocentridae, Chaetodontidae, Pomacentridae, Muridae, Siganidae, and small-sized species of Serranidae, Lethrinidae, Balistidae, and Labridae. Some species of Tridacna are widely distributed and are targeted by islanders when grown large enough to harvest and eat, while the harvest of small-sized individuals is prohibited. Pearlshell (perhaps Pinctada marginifera) formerly inhabited Tokelau's lagoons, and once were utilised to produce lure shanks, though this species was very limited in Atafu (Macgregor 1937). It may have been locally extirpated from Tokelau by the 1950s, when it was reported that 10 years had passed since any pearlshell was found on Fakaofo (Van Pel 1958). Other important invertebrate species include about ten species of crab, such as tupa (a land crab, Cardisoma sp.), uganga (coconut crab or Birgus latro), and kamakama (rock crab or Grapsus sp.) are also common around the lagoon coasts, and are usually exploited as food or fishing bait.

The ocean-side coasts are surrounded by narrow coral reefs that have a greater variety of fish and mollusc species than the lagoons. The major fish inhabiting the outer reefs are various species of Scaridae, Labridae, Balistidae, Acanthuridae, and small species of Carangidae, Serranidae, Lethrinidae and Lutjanidae which mainly swim around reef edges. For molluscs, some species of Turbinidae and Trochidae inhabit mainly the reef edges, but in recent times only Turbo shells are taken to eat. According to Passfield (1988), Trochus is not native to Tokelau but was introduced to the atolls in 1986 from Fiji as part of a development project. Some larger fishes inhabit the outer reef waters, particularly between the reef edges and the pelagic ocean. They are species of Carangidae, Scombridae, Lutjanidae, Serranidae, Sphyraenidae, and shark species. Flying fish (Cypselurus sp.) and sea turtles are also mainly captured in this biotope. 
Wild bird species inhabit the islands, and Tokelauans still occasionally capture wild birds for food (Huntsman and Hooper 1996; Matagi Tokelau 1991). Seabirds, such as terns and noddies (lakia), are generally caught with nets and nooses (Matagi Tokelau 1991: 201). There are no terrestrial mammals native to Tokelau; all are introductions either by the early Polynesian settlers or later European visitors. Archaeological finds (Addison and Kalolo 2009; Best 1988) suggest that the first people to arrive at Tokelau brought with them the dog (Canis canis) and the Polynesian rat (Rattus exulans). Dogs were no longer present in Tokelau at European contact. Tokelauans have no tradition of dogs, either as a source of food or of companionship and they are not kept today. $R$. exulans are still found in Tokelau along with recently introduced rat species; rats are now considered a pest. Pig (Sus scrofa) was introduced to Tokelau after European contact. The timing of the introduction of chicken is ambiguous.

\section{The People and Language}

In terms of population in Tokelau, Atafu is the most populous with -600 people, followed by Fakaofo with $\sim 500$, and Nukunonu with $\sim 400$ (Statistics New Zealand 2001); Olohega currently has fewer than 20 people. Tokelau has been an incorporated territory of New Zealand since 1948. Over 1,500 Tokelauans now live on the main islands of New Zealand (Statistics New Zealand 2001), with several thousand more Tokelauans living in Samoa, Hawai $i$, and Australia. Although Olohega is currently part of the American Samoa, many Tokelauans consider it a historical and cultural part of Tokelau (Matagi Tokelau 1991:41-43).

The people of Tokelau are Polynesian, with strong affinities to the atoll peoples of Tuvalu to the west, and the Northern Cook Islands to the east. Interaction to the south with Samoa has been an important process for at least the last century and possibly much longer. However, oral tradition is silent on the earliest origins of the Tokelau peoples (Huntsman pers. comm.; Huntsman and Hooper 1996; Matagi Tokelau 1991). Archaeologically, the Lapita cultural complex is the first indication of people in West Polynesia at -3000-2800 cal BP (e.g., research summarised in Kirch 1997). In the "Hawaiki" model (Kirch and Green 2001), an "Ancestral Polynesian Society" (APS) with unique cultural and linguistic traits developed in the Fiji, Tonga, Samoa, Uvea, and Futuna area over the following millennium of regular interarchipelagic contact. A dialect chain developed over this area and eventually split into a northern and southern branch. At $-1300-1100$ cal BP and subsequent to this breakup, East Polynesia and the Polynesian Outliers were settled, mostly from islands speaking the northern branch of the dialect chain - Proto Nuclear Polynesian (Green 1966, 1988; Marck 2000; Pawley 1966, 1967).

Tokelau was probably first settled during this period of expansion. The previous archaeological excavations in Tokelau (Best 1988:104) dated unidentified charcoal from basal cultural deposits on Atafu to $1150-690 \mathrm{cal} \mathrm{BP.}{ }^{1}$ On Fakaofo, turtle bone from the lowest cultural deposits dates to 790-530 cal BP (Best 1988: 115). The apparent discrepancy between these two dates could be resolved by arguing that the area of overlap represents the actual initial settlement period for Tokelau. Coconut endocarp excavated by our research in 2008 from a basal cultural layer about 100m from Best's 1986 sample location dates to 660-550 cal BP (Addison et al. 2009; Addison and Kalolo 2009; Petchey et al. under review), further reinforcing the idea that the overlap in Best's basal dates is the actual period of initial colonisation. Many more dating samples from a variety of stratigraphically secure contexts on all three atolls will be required to resolve this question.

1 Reported at 20, calibrated using OxCal v3.10 with InterCAL04. For justification for Northern-Hemisphere curve (see Petchey and Addison 2008 and also Addison and Asaua 2006). 
The Tokelauan language is typically Polynesian. It contains five vowel sounds (written as a, e, i, o and $\mathrm{u}$ ), and ten consonants (written as $\mathrm{f}, \mathrm{g}, \mathrm{h}, \mathrm{k}, \mathrm{l}, \mathrm{m}, \mathrm{n}, \mathrm{p}, \mathrm{t}$, and $\mathrm{v}$ ). The $\mathrm{f}$ is pronounced like wh, and the $\mathrm{h}$ is a glottal fricative, while it sounds the same as English h before the vowels $\mathrm{i}$ and e. On the other hand, before the back vowels a, o, and $\mathrm{u}$, is pronounced more like hy (e.g., Tokelauan Dictionary 1986). The last century has seen an increase in cultural and linguistic influence on the Tokelauans by Samoa, and this has affected some of the names of plants (Whistler 1988). Some Tokelauan fish names have also been affected or introduced from adjacent islands, mainly the Northern Cook Islands, Tuvalu, Samoa, and Tonga (see Hooper 1994; Rensch 1994).

In a comparative linguistic analysis of Proto Polynesian (PPN) and Proto Nuclear Polynesian (PNP) fish names, Robin Hooper (1994) checked for shared retentions and innovations, or borrowings between Polynesian islands. Her analysis indicates that out of 112 PPN reconstructions for fish names, Tokelauan retains reflexes of 94 (84\%), which is an extraordinarily high figure (Hooper 1994:187). As Hooper mentions, the high figure for Tokelauan could indicate either a more nearly complete inventory of local fish names than other islands, or the more conservative nature of the Tokelauan lexicon (Hooper 1994:187). In any case, it is clear that Tokelauan fishing terms and fish names are good candidates for inclusion in core vocabulary lists for the region.

\section{A Brief Sketch of Atafu}

Here, we briefly describe Atafu, its people and social structure. Atafu is located at the northwest end of Tokelau, which is the part of Tokelau most distant from Western Samoa $(600 \mathrm{~km})$. There is ship transport roughly every two weeks between Western Samoa and Tokelau, and it usually takes about 48 hours from Samoa to Atafu via Fakaofo and Nukunonu. As noted earlier, Atafu is the smallest atoll in Tokelau both in lagoon size and land area. The only village is on an islet at the northwest corner of Atafu. The current human population is -600 . Atafu's other 41 islets have no permanent human habitations (Figure 2).

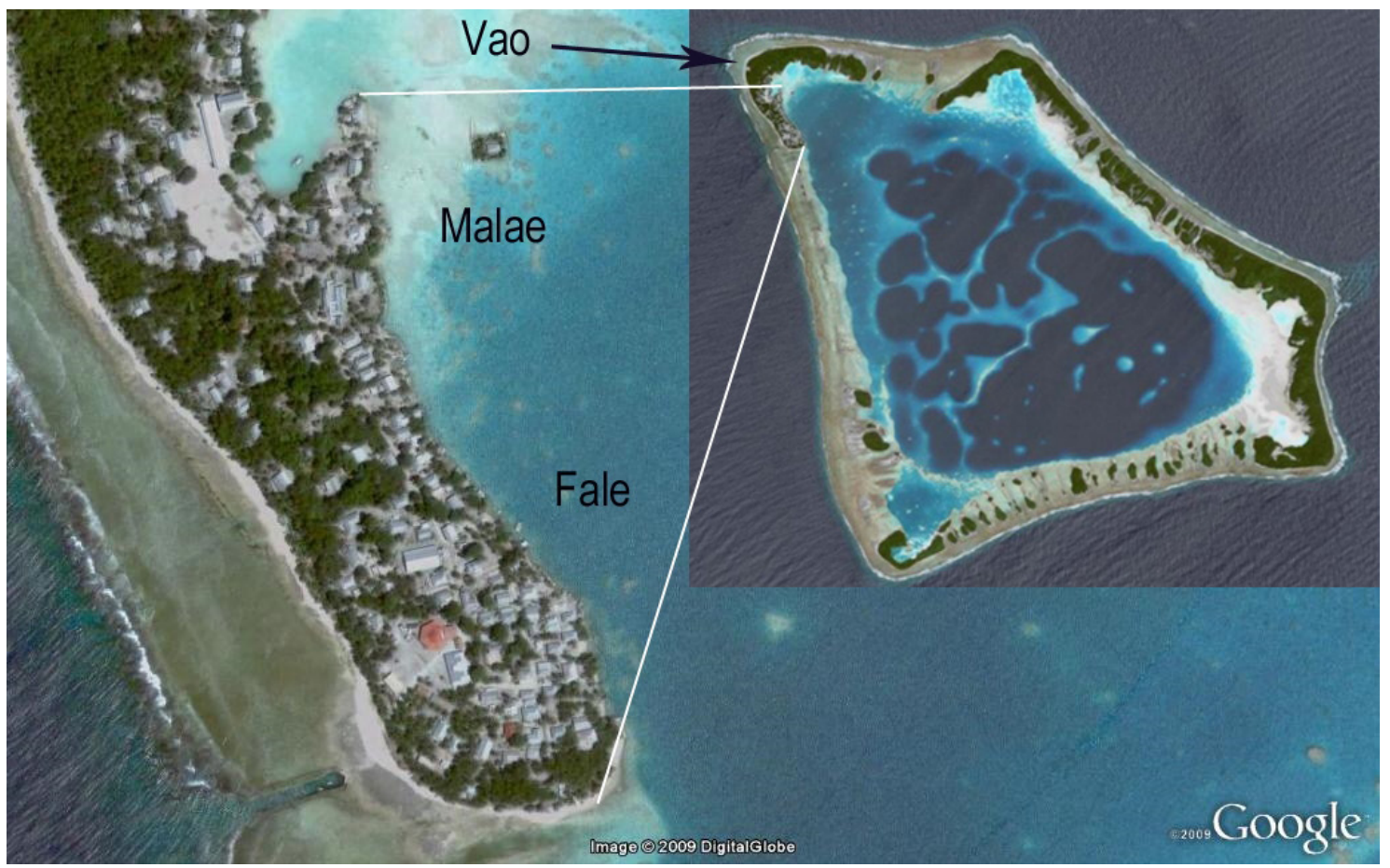

Figure 2. Atafu Atoll and the village location on Vao Island.

Source: Map by authors, based on Google Map. Retrieved from http://maps.google.com 
The subsistence activity of the Atafu people falls into three major spheres: fishing, root-crop cultivation, and fruit-tree harvesting. Coconut gardens are used for human and pig food. Traditionally, only men were allowed to fish on the outer reefs, while fishing and gathering in the lagoon and on the reef were also practised by women and children. Large repertoires of fishing techniques and strategies $(-120)$ were formerly employed throughout the lagoon, inner reef, and outer-reef-to-offshore zones of Atafu (Mafutaga a Toeaina o Atafu i Matauala Porirua 2008). A variety of coral-reef fish, sharks, sea turtles, pelagic fish, and some invertebrates were caught by use of seines, hand nets, stone weirs, lines, spears, ropes, and lures. Gathering of molluscs, crabs, and other marine resources were also occasionally practised. The range of techniques and strategies has considerably narrowed in recent decades (Mafutaga a Toeaina o Atafu i Matauala Porirua 2008).

The major root crop cultivated on Atafu is giant swamp taro (pulaka or Cyrtosperma chamissonis), which is mainly cultivated on some of the large islets on Atafu's west and south west sides where the Ghyben-Herzberg freshwater lens is easily accessible from the surface. Villagers must travel to the islets where their gardens are located to maintain and cultivate their land and crops. Besides root crops, some fruit trees such as coconut, breadfruit, banana and pandanus are also cultivated both in the village and on other islets. Among them, coconut has also been planted for copra production. Copra was the major commercialised economic crop of Atafu for some decades, but is no longer exported.

Some pandanus-leaf crafts such as hats and bags made by women and wooden carvings produced by men are exported. An annual grant provided by the New Zealand government is used for building and running public services including roads, the hospital, the power plant, and the school. The main shop on Atafu is a cooperative run by the community, and it imports various foods and other products. These public services are administered by a council of male elders known as the Taupulega o Atafu. A council of women, the Fatupaepae, and a men's society, the Aumaga, are each responsible for coordinating other important economic, social, and cultural activities.

\section{Tokelauan Fishing Lore and Fishing at Atafu}

The people of Tokelau use the term faiva ${ }^{2}$ to refer to the capture of all edible animals (Matagi Tokelau 1991). The most important of these activities is fishing (Gillett 1985). Traditionally, a great range of fishing techniques was employed in Tokelau, including various methods of angling, netting, trapping and spearing. Gillett (1985) reports that some traditional fishing methods such as casting for skipjack with pearl shell lures has been seldom practised in Tokelau since the 1980s, while some new and modern fishing methods and gear are widely employed.

Most of such fishing activities on Atafu and other Tokelau atolls are also closely related to the phases of the moon as well as the seasonal cycle (see Ono and Addison 2009). For instance, Tokelauan atolls are occasionally struck by cyclones during the November-to-March period, while rather mild south-east trade winds blow during the May-to-November period. Because outer-reef-to-offshore fishing of the inhabited side of islands is periodically difficult or impossible during the cyclone season, fishing activities are more actively pursued during May to November, and the season is regarded as the best fishing season on Atafu and other atolls in Tokelau (see also Gillett 1985; Hooper 1985; Matagi Tokelau 1991). The detailed classification and terms of the lunar cycle on Atafu and other atolls in Tokelau indicates that the lunar and tidal cycle is also important for fishing activities, and some inshore and offshore fish species are well known and recognised to have seasonality by the people in Tokelau (see Ono and Addison 2009:Table 1).

2 However, "Faiva" does not just refer to fishing/hunting (Tokelau Dictionary 1986). 
In Tokelau, traditional fishing lore and knowledge was closely related to the "tautai" title system. This title was a status which could be achieved only by men. It can be glossed as "master fisherman" - someone who has a considerable amount of expertise in the entire spectrum of fish-catching methods and also the leadership skills and experience necessary for directing and managing fishing expeditions (e.g., Gillett 1985; Hooper 1985, 2010; Matagi Tokelau 1991). Traditionally, until achieving tautai status, a young man was not supposed to take the stern seat in a canoe, the position from which all operations were directed (Hooper 1985). After years or decades of instruction, he would be eligible for a kau kumate ceremony in which the title of tautai was conferred. ${ }^{3}$ However, there have been no kau kumate held since the late 1970s in Tokelau (Hooper 1985).

On contemporary Atafu and other Tokelau atolls, basically three types of fishing zones are identified: offshore (tuakau), reef (uluulu) and lagoon (namo). Although each of these three zones is characterised by a set of distinctive fishing methods, there is considerable overlap in the types of fish that are commonly caught across the three zones. Beside these three zones, land and beach zones are also recognised as part of fishing areas on Atafu (Mafutaga a Toeaina o Atafu i Matauala Porirua 2008), particularly in relation to bait for fishing, as some important bait species such as coconut crab (ugauga) are caught ashore. Here, we first briefly introduce the major fishing in each fishing zone and secondly discuss the material culture of fishing and aspects of marine conservation in Tokelauan fishing.

\section{Outer-reef-to-off-shore fishing}

According to Atafu informants, offshore fishing is more important than reef or lagoon fishing, because of the relatively small size of their lagoon. In fact, the book written and published by the Atafu-born elders living in New Zealand (Mafutaga a Toeaina o Atafu i Matauala Porirua 2008) reported 47 methods of offshore fishing against 29 methods for lagoon fishing and 45 methods for reef fishing on Atafu. The number and variety in methods are largest for the offshore fishing zone. Most of the fishing activities observed during our stay on Atafu in August 2008 and on July 2009 were on the outer reef or offshore.

Casting a hook or lure for atu (skipjack or Katsuwonus pelamis) and kakahi (yellowfin tuna or Thunnus albacares) has probably been the most important single type of fishing practised traditionally on Atafu, both economically and socially (e.g., Gillett 1985; Hooper 1985; Hooper and Huntsman 1991; Huntsman 1990; Macgregor 1973; Matagi Tokelau 1991). This pattern continues today. Skipjack fishing is called alo atu or just alo. Decades ago, this involved paddling through a group of shoaling fish while casting a hook and lure. Today, aluminium boats with outboard engines are commonly used for outer-reef to offshore fishing including alo atu, although some Atafu fishermen maintain the tradition of using wooden outrigger canoes (albeit with outboard engines).

Skipjack and yellowfin tuna fishing is traditionally a communal, family, or fishing crew based activity involving a number of boats (see also Hooper 2008 and Hooper 2010 for the Fakaofo case in the 1970s). ${ }^{4}$ Skipjack went to inati and yellowfin to inati or kaiga depending on what kind of fishing the Taupulega decreed, then catch from the kaiga canoe was taken to the fatupaepae who shared it to the family and to members of the crew who were not of the kaiga.

Hahave (flying fish or Cypselurus sp.) are usually caught at night in waters close to the shore using scoop-nets called heu and torch light. This fishing is called lama hahave (lama = torch) on Atafu,

3 The detail of the kau kumate ceremony are described by Hooper (1985:18-26) and other documents (e.g., Matagi Tokelau 1991:177-179).

4 Among them, skipjack was communal, highly controlled fishing, while yellowfin was usually by family fishermen and far more

common in Atafu, where the bait-fish (uli) were used. 
and traditionally coconut leaf torches were used (see also Mafutaga a Toeaina o Atafu i Matauala Porirua 2008). Catches of up to three hundred fish per night are not uncommon (Passfield 1998). Hahave are available throughout the year, but are most abundant July through October. During this time of year, they are consumed in greater numbers than tuna (Passfield 1998), although they are a much smaller fish, growing to a length of around $25 \mathrm{~cm}$, and with a weight of about $300 \mathrm{~g}$ (Froese and Pauly 2002). Similar fishing methods with scoop-nets are also employed to catch talagogo (a seabird species, possibly Sterna fuscata) on the outer reefs during the day time.

Noosing pala (wahoo or Acanthocybium solandri) is also a well-regarded traditional fishing method in Tokelau (Matagi Tokelau 1991) and it is called takiulu. A small baitfish, such as a flying fish is towed behind a canoe to lure the pala into a prepared noose, which catches the fish by the tail. Groups of hakula (marlin or Xyphias gladius), kakahi (yellowfin tuna or Thunnus albacares), and mago (sharks) were also occasionally caught using this method. Among these, hakula is traditionally regarded as one of the sacred fish ( $i k a ~ h a)$ by the Atafu people and its meats are equally distributed to each household with the inati system. Both inshore and deep-sea (80-100 fathoms) shark fishing with large hooks and lines is another popular fishing method, particularly for elders who relish shark meat, especially the liver. Deep-sea shark fishing called fakatu (Mafutaga a Toeaina O Atafu I Matauala Porirua 2008: 106), is a rather new method developed in the early 20 $0^{\text {th }}$ century (Matagi Tokelau 1991:191). Pala and ono (barracuda or Sphyraena barracuda) are also caught using this method.

Sea turtle $(f o n u)$ is one of the important catches in traditional fishing among all the atolls of Tokelau (Matagi Tokelau 1991:188). Although there are different methods to catch sea turtle, the most popular method is to catch a pair of mating turtles, usually as two men swim to the turtles, each seizing a turtle (see also Macgregor 1937:99-100). There were also many traditional restrictions (lafu) for turtle fishing, such as a man whose wife was pregnant, who was not allowed to join a fishing party since his presence with the team would make the turtles timid and shy (Matagi Tokelau 1991:189). Turtle was regarded as one of the sacred marine resources $(h a)$ by Atafu people, and meat was equally distributed to each household by the inati system similar to other sacred species such as skipjack tuna and marlin. The season of turtle fishing is closely related to the turtle's mating period, usually September to November on Atafu. As in most Pacific countries, today turtle fishing is officially prohibited throughout Tokelau.

\section{Reeffishing}

For reef fishing, fishing with nets (kupega, heu, kalele) is the most common technique practised today in Tokelau (see also Passfield 1998), while angling (hi) is also actively employed on Atafu (Mafutaga a Toeaina o Atafu i Matauala Porirua 2008). In the recent past, nets were made locally, using $30 \mathrm{~kg}$ breaking-strain monofilament. Passfield (1998:10) reported that mesh size ranged from $1 / 2$ in. $(12.7 \mathrm{~mm})$ to $4 \mathrm{in}$. $(100 \mathrm{~mm})$, with $2 \mathrm{in}$. $(50 \mathrm{~mm})$ being the most common size. Although most of the nets used today on Atafu are commercial products made of nylon filament, the techniques of netting are quite similar to those of the recent or traditional past; nets are usually set on the reef flat to catch fish moving in and out of the lagoon. Fishing with a net attached to a circular wooden frame which can be closed by pulling a line is called tata, and is commonly employed in the reef zone.

Smaller and long-handled scoop nets (heu) are used by groups of two or three people to catch groupers (e.g., Epinephelus melanostigma, Epinephelus merra, Epinephelus hexagonatus) and squirrelfish (Myripristis sp.) on Atafu (see also Mafutaga a Toeaina o Atafu i Matauala Porirua 2008:86-88). Large scoop nets (kalele) were frequently used for fishing in outer reef channels (e.g., Macgregor 1937:95), and this method is called tatago on Atafu. On Atafu today, large netting drives with seines (talitali) are also occasionally employed for commual fishing involving 
over 100 people (men and children but not adult women). Fish captured by such netting include high numbers of ulahi (Scarus harid), umeihu (Naso unicornis), umelei (Naso lituratus), kanae (Mugil cephalus), and nanue (Kyphosus cinerascens). ${ }^{5}$

Fishing with a hook (mataulkafilo) and line (uka) is occasionally practised, mainly around reef channels on Atafu today. Among 45 traditional fishing methods mainly employed in reef zones, 13 are recognised as hook-and-line fishing (Mafutaga a Toeaina o Atafu i Matauala Porirua 2008). Interestingly, most of these hook-and-line fishing methods are named and identified with targeted fish names such as hi gatala (gatala = Epinephelus quoyanus), hi patuki (patuki $=$ Cirrhitus pinnulatus or hawkfish in general), hi api (api=Acanthurus guttatus), hi mutu (mutu=Abudefduf sp.), and hi ulafi (ulafi = Hipposcarus longiceps or Scarus harid). In recent times, lures are also used where the sea bottom is sandy (so that hooks do not get snagged).

Stone weir fish traps (fota) were also used as one of the traditional fishing methods on Atafu. However, the use of such stone weirs ended by the late 1970s. On Atafu, basically two types of fota were built and employed; the former one is called fota tali ihe and mainly aims at school of Caranx sp. The trap is a fota about 60 feet long with the mouth facing the land and lagoon side. The other is called tali ihe i na fota and is mainly aimed at schools of garfish with a trap about 60 feet long, with the mouth also facing toward land (Mafutaga a Toeaina o Atafu i Matauala Porirua 2008: 55-58). Our interviews with elder men confirm that there were at least two of each fota on Atafu in the late 1970s. Huntsman and Hooper (1996:24) report that traps were constructed beside the shallow passes in the reef to catch fish on their spawning runs from the lagoon to the sea. While most traps were operated communally, some were owned and operated by individual families (Matagi Tokelau 1991).

Fishing methods aimed at octopus (feke) and crayfish (ula) was also mainly employed in the reef zone. The capture method of octopus, called fagota feke, mainly consist of three different methods: (1) fagota feke, capture using a wooden stick made from specific tree called gagie (Pamphis acidula) and fishing string called kalava made from the outer skin of a coconut frond petiole (which attracts the octopus so it can be caught); (2) taki feke, fishing with an octopus lure (pule takifeke) made from a large cowrie shell (pule) and pandanus leaf (laufala); and (3) toko feke, capture using a metal rod at low tide. A canoe was occasionally used for moving around the reef to seek octopus. The capture method of crayfish called holi ula, in which feet and hands are used to catch crayfish during a rising tide on a moonlit night when the crayfish come out to feed (Mafutaga a Toeaina o Atafu i Matauala Porirua 2008:46). Among these, toko feke is the main capture method used today.

\section{Lagoon fishing}

On Atafu, lagoon fishing is not considered as productive as open-sea fishing, and is often only done when the weather prohibits going out to sea, especially during the hurricane season between November and April. A number of different species are caught with hook and line. Among 29 fishing methods mainly employed in the lagoon, 16 are recognised as hook-and-line fishing (Mafutaga a Toeaina o Atafu i Matauala Porirua 2008:23). Similar to reef fishing, most of these line fishing methods are named and identified with targeted fish names such as hi kulapo (kulapo

\footnotetext{
5 We had a chance to observe the large netting drive during our stay on 11 July 2009. The netting was practised as the community fishing during the Aumaga festival with over 100 men involved. The fishing was started around noon for about an hour to catch $\sim 480-$ $600 \mathrm{~kg}$ ( 25 baskets each of which was $-20-25 \mathrm{~kg}$ ) of inshore fish. All the fish captured were distributed equally to each household with inati system, and our count of each fish species confirm that ulahi (305 specimens), umelei (240 specimens), and umeihu (81 specimen) are major captures and far exceed other species in number and weight.
} 
= small-sized Scarus harid or Hipposcarus longiceps), hi mu (mu = Monotaxis grandoculis), hi umu ( umu = Balistoides viridescens), hi mutu (mutu=Abudefdufsp.), hi papo (papo= Cheilinus fasciatus), and hi kafa (kafa $=$ Liza vaigiensis or Liza subviridis).

Flying fish moving into the lagoon are also targeted by line fishing during the daytime and this method is termed as hi havane ite ao (ite ao = during daytime). Line fishing is also employed at night to catch gatala (Epinephelus quoyanus) and talatala (Myripristis violaceus). The one to catch gatala is termed hi gatala $i$ te tete, and another one to catch talatala is termed hi talatala. Swimming fishing with goggles and line is called fakatakoto. Octopus meat is mainly used for the bait for this kind of fishing (Matagi Tokelau 1991:201). Sometimes a sack full of coral gravel is tipped into the lagoon to attract fish before the line is cast. This is known as tuki akau (Matagi Tokelau 1991:200) or tuki toka (Mafutaga a Toeaina o Atafu i Matauala Porirua 2008:35).

Smaller hand and scoop nets ( heu) have been also used by groups of two or three people in lagoon fishing. The major fishing with heu is called lama ihe, which aims to catch garfish or half-beak (ihe = Hemiramphidae and Belonidae) inside the lagoon at night. Baskets ( $f a g a$ ) made from the gagie tree are also used in lagoon fishing. Some net fishing such as tata (see the description in reef fishing) and tali tafega, which targets some fish species moving between reef and lagoon during low tide, are employed as lagoon fishing methods (Mafutaga a Toeaina o Atafu i Matauala Porirua 2008:41). Basket traps were also employed mainly in the lagoon on Atafu and other atolls in Tokelau. Macgregor (1937:94) reported that he did not see basket traps at Atafu during his visit in 1932, although he saw a few of one type at Fakaofo and Nukunonu. Our interviews confirm that there were some at Atafu in the recent past, though none were seen at Atafu during our stay. Such basket traps might not be commonly used in Tokelau, particularly at Atafu with the smallest sized lagoon in Tokelau.

Gathering molluscs is also part of lagoon fishing. Giant clams (fahua or Tridacna maxima and Tridacna squamosa) are regularly harvested from shallow parts of the lagoon, and they are levered from below the water with a knife-like instrument called a nao; this fishing technique is called naonao fahua (Mafutaga a Toeaina o Atafu i Matauala Porirua 2008:37). At present, there is some concern over the diminishing abundance of clams (e.g., Toloa et al. 1994). The introduction of underwater goggles and the recent development of commercial harvesting for the export market have both contributed to the decline in clam numbers (e.g., Gillett 1985; Passfield 1998). The Taupulega on Atafu has now imposed strict limits on Tridacna harvest.

\section{Material culture of fishing}

Gear and equipment associated with fishing have changed since prehistoric times, particularly subsequent to contact with the Western world. Historical evidence indicates that Tokelauans used lines, hooks, lures, rods, nets of various kinds, as well as traps and stone weirs before European contact (e.g., Hooper 1985; Macgregor 1937). Archaeological research on Fakaofo and Atafu by Best (1988) unearthed four one-piece pearl-shell or bone hook fragments and recovered a complete pearl-shell lure shank.

Traditionally, the hook portion of the lure was made from the shell of fonu una (hawksbill turtle or Eretmochelys imbricate), while in modern times cow horn, coconut shell, whale teeth, marlin spikes, aluminium and plastic are also occasionally used (Gillett 1985). Typologically, historicperiod Tokelau lures styles, with attachment of the leader line to both the head of the pearl-shell shank and to the base of the turtle shell hook, conform to the typically West Polynesian types such as those from Samoa, Pukapuka, Tuvalu, Wallis and Polynesian outliers in Melanesia (e.g., Anell 1955; Gillett 1985; Hiroa 1932; Macgregor 1937). 
The records of the United States Exploring Expedition (Hale 1846; Wilkes 1845), which visited Atafu and Fakaofo in 1841, mention the people's extreme eagerness to trade for metal fish hooks and pieces of iron for making hooks. Gillett (1985) reported that pearl-shell was also brought to Tokelau from Papua New Guinea by Tokelauan missionaries during the early 1940s. The shells were also imported from other localities including Pukapuka and Nassau in the Northern Cook Islands and finished lure shanks from Samoa (Gillett 1985). This evidence indicates the eagerness of Tokelauans for exogenous material for making fishing gear, especially pearl shell. This may suggest a motivation for extensive voyaging in prehistoric times, supporting archaeological evidence for Tokelau long-distance exchange in basalt and ceramics (Addison and Kalolo 2009; Addison et al. 2009; Best 1988; Best et al. 1992).

By the late 1960s, imported fishing equipment had almost entirely replaced items of local manufacture, except canoes. Cotton lines, which had supplanted lines made of coconut sennit or other braided fibres such as Hibiscus tiliaceus since the early $20^{\text {th }}$ century, are now completely replaced by monofilament nylon lines (e.g., Hooper 1985). Nets used to be locally made with braided sennit or other fibers but now are also replaced by nylon. Spears are not so actively used in Tokelau, while spear-guns and goggles have been more in use since their introduction during the $1940 \mathrm{~s}^{6}$ The use of pearl-shell lures stopped or dramatically decreased by the early $1970 \mathrm{~s}$ (Gillett 1985; Hooper 1985, 2010), and most of the hooks have been made from metal. The traditional pole for skipjack fishing was made from the wood of puka (Hernandia nymphaeifolia), while imported bamboo has been used in recent times (Gillett 1985) as well as fibreglass fishing poles.

A variety of plant woods were used in the manufacture of fishing gear until a few decades ago. For example, to build a traditional canoe, kanava (Cordia subcordata) was used for the hull and outrigger spars, gagie (Pemphis acidula) for the attachment of spars to outrigger, and puka (Pisonia grandis or Hernandia nymphaeifolia) for the outrigger (Gillett 1985; Whistler 1988). Breadfruit wood has also been used for the hull on occasion (Huntsman pers. comm. 2009). All terrestrial resources are owned and controlled by kaiga (extended family unit in the sense that they jointly own resources and co-operate in exploiting them), which is one of the traditional social structures in Tokelau. Canoes also were unequivocally kaiga property in the past. Until the 1970s, each extended family had at least one canoe, and could hardly have existed as an independent unit without it (Hooper 1985). However, the number of traditional canoes has been decreasing since the 1970s, after the widespread introduction of aluminium skiffs and outboard engines. ${ }^{7}$

Today on Atafu, traditional canoes are a common site beside houses and around the village, though most are in disrepair and currently seldom or never used. People mainly use aluminium skiffs, although several traditional canoes are regularly maintained and used. Both skiffs and canoes are propelled by outboard engines and are regarded as the property of individuals or of married couples now, and no longer of kaiga (see also Hooper 1985 for the Fakaofo case). This may be an example of the rapid replacement of traditional gear and materials for fishing by the introduced modern ones since the middle-to-late $20^{\text {th }}$ century, weakening the tight connections that formerly existed between material culture, the social system, and the island ecosystem.

\footnotetext{
6 Gillett (1985) suspects the introduction of diving goggles to Fakaofo in the 1940s was a major factor contributing to the virtual absence of pearl-shell in the lagoon by the 1950s.

7 For example, Hooper reported that about 60 canoes were in serviceable condition at Fakaofo in 1971, while their number had decreased to only 8 in 1981 (Hooper 1982:31).
} 


\section{Marine conservation measures}

A number of measures are in place in contemporary Tokelau societies that act to limit the exploitation of certain taxa (McAlister 2002:34). One of the most important conservation measures is the periodic imposing of a lafu, or use-restrictions, on specific areas of the reef by the Taupulega (Toloa et al. 1994). In addition to protecting fisheries that are periodically depressed because of human exploitation and seasonal changes, a lafu is sometimes declared to ensure that fish stocks are built up in anticipation of future needs for specific events, such as important festivals (Toloa et al. 1994). On contemporary Atafu, for example, most of the reef fronting the islet where the village is located is restricted from private fishing, and only communal fishing (faiva fakamua) is allowed at certain times of the year as described by Toloa and colleagues (Toloa et al. 1984).

The distinctive inati system of distribution practised in the atolls is another aspect of Tokelau fishing strongly related to marine conservation. All resident members of the village are assigned to an inati group, often on the basis of kin relationships, but sometimes for a variety of other reasons (Passfield 1998). In this system, certain types of fish are considered as ha (sacred), meaning that they must be shared among the village when they are caught. As described above, these sacred fish (ika ha) were traditionally fonu (sea turtle), hakula (billfish/marlin), and atu (skipjack tuna), and they were divided among the whole population through the inati system on Atafu and the rest of Tokelau (see Hooper 1985). Even today, fonu and hakula are still regarded as ika ha, while atu is usually not, except in cases when there is an especially large catch. In effect, the inati system deters the exploitation of these taxa by reducing individual incentives for capturing certain animals. Other species mainly of reef fish are also distributed through the inati, particularly at the time of communal fishing.

\section{Reconstructed Prehistoric Fish Use on Atafu}

\section{Archaeological background}

On Atafu, prehistoric remains are concentrated on a single motu where the village is currently located. The atoll was archaeologically excavated by Simon Best (1988) in 1986. He excavated 14 test units (nine $2 \times 2 \mathrm{~m}^{2}$ and five $2 \times 1 \mathrm{~m}^{2}$ ) on the village islet. Eleven of them ran the length of the contemporary village and were situated about 50 metres apart and about 40 metres from the lagoon shore (Best 1988:106). His excavations confirmed that each test unit had different character and stratigraphy, with some units possibly part of a burial area (e.g., Unit 5), whereas some units were possibly part of habitation areas with significant amounts of faunal remains, mainly fish and bird bones (e.g., Unit 9). The deepest deposits, with several stratigraphic layers down to over 2 metres, were only found around the middle part of the islet (Units 10 and 11) in his excavation. Some ${ }^{14} \mathrm{C}$ dates were also acquired; the oldest date from the charcoal at the lower layer of his Unit 5 is $1000+/-100$ BP (Best 1988: 115; see Petchey et al. 2010 for a review of Tokelau's radiocarbon chronology). Although the number and variety of excavated artefacts were not larger than those from Fakaofo, Best excavated some pieces of potsherds, stone and shell adzes, shell-made fish hooks, and faunal remains on Atafu. For the faunal remains, pig, dog, rat, turtle, bird, fish and shell remains were excavated, while pig remains were found only from upper layers possibly dated back after the European contacts (Best 1988:116).

Based on his previous excavations in the 1980s, we opened eight $1 \times 1$ metre test units (TU 1 , 2, 3, 4, 6, 7, and 8) on Atafu during 2008 and 2009. All the ${ }^{14} \mathrm{C}$ dates obtained by the previous study (Best 1988) and our recent excavations are shown in Figure 3. 


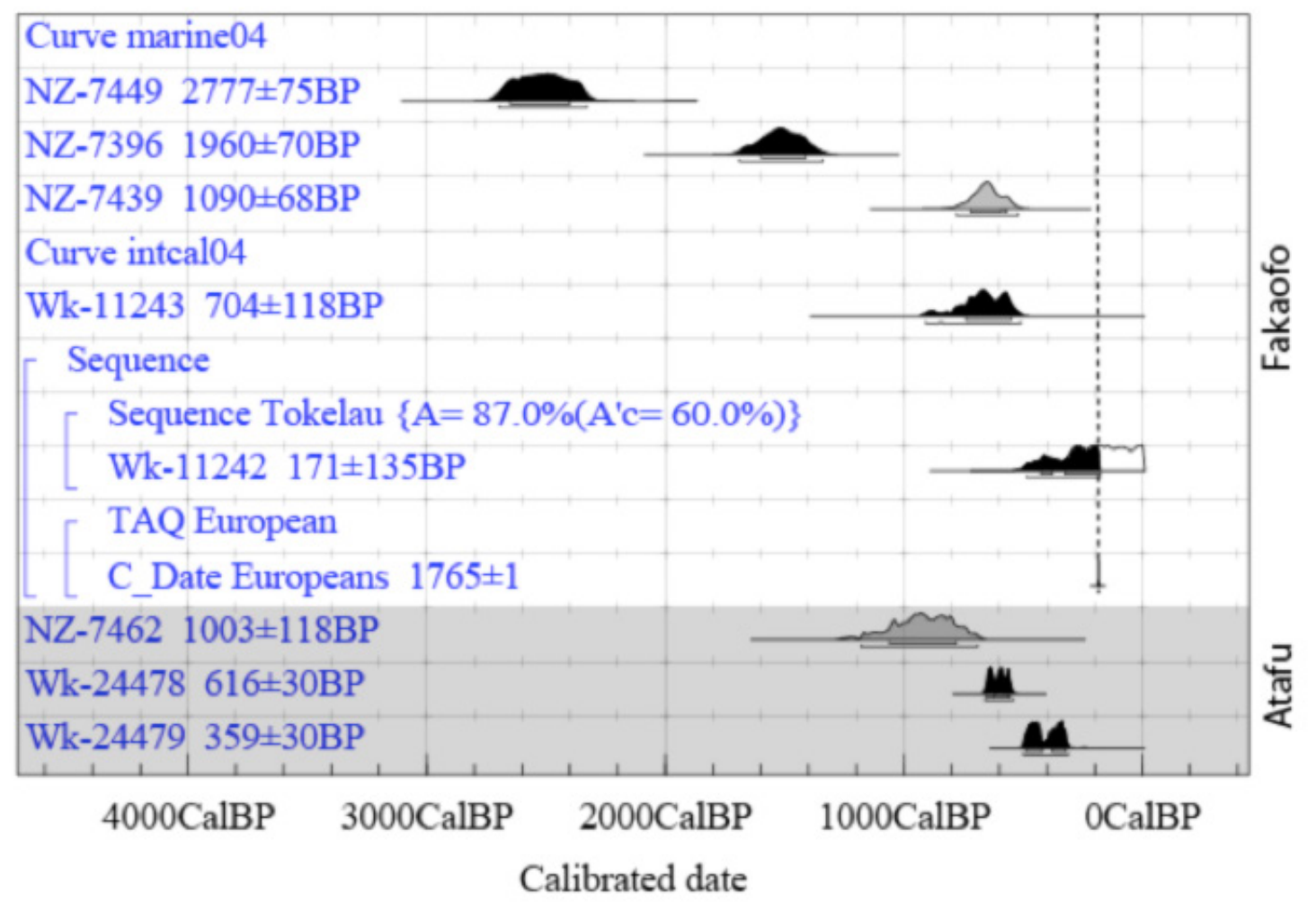

Figure 3. All the ${ }^{14} \mathrm{C}$ dates obtained on Atafu.

* 2009 calibrated radiocarbon ages for Tokelau. Black probability distributions = identified charcoal and shell/coral determinations. Dark grey= unidentified charcoal and turtle bone determinations.

Source: After Petchey et al. 2010.

\section{Methodology of fish bone analysis}

The water sieving with 3,5 and $7 \mathrm{~mm}$ mesh was employed at all units to compare the different recovery method of sieving by different mesh size. After the excavation, all the fish remains together with other faunal remains and artefacts were borrowed under the permit by Tokelauan government, and brought to The Australian National University for further analysis. In this stage, however, we only selected the fish remains sieved by $1 / 2$ and $1 / 4$ inch screen for the identification as there were too many small and tiny bones recovered by $1 / 8$ inch screen.

The methods of fishbone analysis here closely followed the technique developed by Ono and others for the treatment of tropical fish remains from Island Southeast Asia (e.g., Campos 2009; Ono 2003, 2004), Oceania (e.g., Intoh and Ono 2006; Leach 1986; Leach and Davidson 1977; Ono and Intoh 2011; Vogel 2005) and Okinawa (e.g., Toizumi 2007). Cranial elements, special elements, vertebrae and teeth were used for identification. The cranial elements used here include maxilla, premaxilla, dentary, articulate, quadrate, pharyngeal clusters, ${ }^{8}$ opercular, ${ }^{9}$ preopercular, hyomandibular, palatine, ${ }^{10}$ cleithrum, ${ }^{11}$ supra-cleithrum, post-temporal, scapula, ${ }^{12}$ ephiyal, and ceratohyal; special elements included the erectile spines of Balistidae (triggerfish) and Acanthuridae

8 Pharyngeal clusters were used for identification of Scaridae, Labridae, and Lutjanidae for this study.

9 Opercular can be used for identification of Mugillidae.

10 Palatine was used of identification of Serranidae and Lethrinus sp. for this study.

11 Cleithrum was used for identification of Siganidae for this study.

12 Scapula can be used for identification of Scaridae and Scombridae, though we could not find any of these on Atafu so far. 
(unicornfish), scale of Ostrachiidae (boxfish), spines of Diodontidae (porcupinefish), scute of Carangidae (trevelley) and Acanthuridae (unicornfish), and caudal peduncle of Scombridae (tuna). Teeth were also used only for identification of sharks, triggerfish, and one species in Lethrinidae (Monotaxis granoculis or sea breams).

Vertebra were also used for the identification for Elasmobranchii, mainly sharks and some bony fish families such as Scombridae, Carangidae, Belonidae, Muraenidae, Siganidae, Balistidae, and Scaridae as the vertebra belonging to these families are diagnostic in their shapes and relatively easy to identify. Thoracic and caudal vertebrae (caudal peduncle) were mainly used. It is also the fact that many of pelagic fishes such as Scombridae are usually much easier to identify by use of vertebrae rather than cranial elements which are much more fragile than those of other bony fishes (see Davidson et al. 1999; Leach et al. 1997; Ono and Intoh 2011).

For the purpose of the analysis, an assemblage was divided as the contents of any single excavation unit. Thus, all bones from one excavation unit and one excavation level were designated as an assemblage. Following the method of Leach (1986), each assemblage was sorted into identifiable and not identifiable piles, and all materials were re-bagged, then identifiable fragments were sorted anatomically and re-bagged again. Taking each part of the anatomy in turn, bones were sorted into species, genera, and families, and identified with reference to the comparative collections. The Minimum Number of Individuals (MNI) and Number of Identified Specimens (NISP) were calculated with the technique of Chaplin (1971), although size mismatches were also taken into account (e.g., Intoh and Ono 2006; Ono 2002, 2004, 2005; Ono and Intoh 2011). The exception is shark vertebrae which have a wide size range in a specimen, thus, the MNI of each shark group is always counted as " 1 " even if there are more numbers and size varieties in the excavated assemblage.

\section{Results}

A total of 8,160 fish bones were counted from the seven of $1 \times 1 \mathrm{~m}^{2}$ units (TU 1, 2, 3, 4, 6, 7 and 8 ) in 2008 and 2009. The total number of bones should be increased when other much smaller bones sieved by $1 / 8$ inch screen are added by further study. The distribution of identified anatomical elements (29 components) in all the excavated sites was indicated in Table 1. Among these elements, vertebrae exhibited the largest numbers. Beside vertebrae, the major anatomical elements of cranial part are (1) premaxilla, (2) dentary (3) maxilla (4) pharyngeal (upper cluster), (5) pharyngeal (lower cluster), (6) articular, and (7) quadrate. The total number of identified fish remains in family levels counted up to 608 (MNI) and 1,655 (NISP) in total. 
Table 1. Number of Identified Elements from Atafu Excavation in 2008 and 2009.

\begin{tabular}{|c|c|c|c|c|c|}
\hline ANATOMY & LEFT & RIGHT & TOTAL & & TOTAL \\
\hline Dentary & 85 & 92 & 177 & Vomor & 22 \\
\hline Premaxilla & 81 & 75 & 156 & Tooth(c) & 19 \\
\hline Quadrate & 60 & 65 & 125 & Posttemporal & 17 \\
\hline Articulaer & 59 & 58 & 117 & Ceratohyal & 14 \\
\hline Maxilla & 44 & 52 & 96 & Tooth(b) & 12 \\
\hline Cleithrum & 39 & 35 & 74 & Postopercle & 11 \\
\hline Preopercle & 30 & 37 & 67 & Palatine & 9 \\
\hline Erectile Spines(A) & & & 95 & Scapula & 9 \\
\hline Scute (Carangids) & & & 75 & Spine(Diodontidae) & 4 \\
\hline Erectile Spines(B) & & & 67 & Scute(A) & 2 \\
\hline Caudal Peduncle & & & 67 & Ulophyal & 2 \\
\hline Pharyngeal (U) & & & 62 & Epihyal & 9 \\
\hline Hyomandibular & & & 57 & Pharyngeal & 9 \\
\hline Pharyngeal (L) & & & 57 & skull? & 48 \\
\hline Supracleithrum & & & 39 & Others & 163 \\
\hline Opercle & & & 34 & Fragments & 3001 \\
\hline Vertebrae (b) & 1752 & & & Total & 8,160 \\
\hline Vertebrae (c) & 106 & & & & \\
\hline Scale & 1132 & & & & \\
\hline Spines & 541 & & & & \\
\hline
\end{tabular}

Source: Table by the authors.

Twenty-six taxa were identified including 22 families and 1 species (Monotaxis granoculis). As shown in Table 2, the MNIs of Scarids (parrotfish) is the highest as they occupied around 15 to $20 \%$ in total MNI in each unit. In some units, the MNI of Scombrids (tunas) exceed that of Scarids and can be recognised as the second major fish species on Atafu. Acanthurids, Serranids and Balistids are also major fish taxa in most units. The relatively high abundance of Holocentirds is another trend in the prehistoric fish use on Atafu. In general, relative abundance of inshore or reef species and outer-reef to pelagic species are equally exploited in most of units. In terms of outer-reef to pelagic species, the shark bones were classified into four taxa including at least 2 families as Carcharhinids and Lamnids based on morphology of its vertebrae. For other fish species, Scombrids, Carangids (trevally or scads) and Sphyraenids (barracudas) are identified. In some units, such as TU 1 and TU 2, the MNI numbers of Scombrids exceed that of Scarids, and occupy the first rank fish exploited in these units.

Similarly, in terms of NISP count, the numbers of Scombrids and Carangids dramatically increase (see Table 3). This may be caused by the larger number of excavated vertebra indentified into these species, and we should stress again that tunas were mainly identified by use of vertebrae and caudal peduncles since the number of these elements was very large, while the number of cranial bones for this family was very limited and far smaller than that of other bony fish species (e.g., Serranidae, Lutjanidae, and Lethrinidae). On the other hand, the total number of vertebrae identified to other bony fish taxa was very small, except Scarids as shown in Table 4, and these taxa were mainly identified by their cranial bones (e.g. premaxilla, maxilla, quadrate, and dentary). 
74 Prehistoric Marine Resource Use in the Indo-Pacific Regions

Table 2. Identified fish remains from each unit* (MNI).

\begin{tabular}{|c|c|c|c|c|c|c|c|c|c|c|c|c|c|c|c|c|}
\hline TU & 1 & & 2 & & 3 & & 4 & & 6 & & 7 & & 8 & & Total & \\
\hline Bony fish & MNI & $\%$ & MNI & $\%$ & MNI & $\%$ & MNI & $\%$ & MNI & $\%$ & MNI & $\%$ & MNI & $\%$ & MNI & $\%$ \\
\hline Scaridae & 16 & 18.6 & 7 & 20.5 & 7 & 19.4 & 9 & 19.4 & 16 & 21 & 19 & 15.9 & 32 & 15.3 & 106 & 17.4 \\
\hline Scombridae & 20 & 23.2 & 12 & 35.2 & 3 & 8.3 & 7 & 14.8 & 12 & 15 & 9 & 7.5 & 11 & 5.2 & 74 & 12.1 \\
\hline Serranidae & 9 & 10.4 & 2 & 5.8 & 4 & 11.1 & 4 & 8.5 & 9 & 12 & 13 & 10.9 & 26 & 12.5 & 67 & 11 \\
\hline Carangidae & 3 & 3.4 & 0 & & 0 & & 3 & 6.3 & 2 & 2.5 & 11 & 9.2 & 8 & 3.8 & 27 & 4.4 \\
\hline Acanthuridae & 9 & 10.4 & 2 & 5.8 & 5 & 13.8 & 1 & 2.1 & 6 & 7.6 & 16 & 13.4 & 58 & 27.8 & 97 & 15.9 \\
\hline Balistidae & 6 & 6.9 & 1 & 2.9 & 1 & 2.7 & 10 & 21.2 & 15 & 19 & 20 & 16.8 & 16 & 7.6 & 69 & 11.3 \\
\hline Holocentridae & 4 & 4.6 & 0 & & 2 & 5.5 & 3 & 6.3 & 4 & 5.1 & 11 & 9.2 & 19 & 9.1 & 43 & 7 \\
\hline Myipeistis sp. & & & 0 & & & & & & & & 6 & & 12 & & & \\
\hline Sargocentron sp. & & & 0 & & & & & & & & 5 & & 7 & & & \\
\hline Labridae & 1 & 1.1 & 0 & & 1 & 2.7 & 1 & 2.1 & 6 & 7.6 & 5 & 4.2 & 12 & 5.7 & 26 & 4.2 \\
\hline Siganidae & 1 & 1.1 & 1 & 2.9 & 0 & & 0 & & 1 & 1.2 & 0 & & 3 & 1.4 & 6 & 0.9 \\
\hline Lutjanidae & 1 & 1.1 & 0 & & 1 & 2.7 & 1 & 2.1 & 1 & 1.2 & 1 & 0.8 & 5 & 2.4 & 10 & 1.6 \\
\hline Sphyraenidae & 1 & 1.1 & 0 & & 0 & & 2 & 4.2 & 0 & & 0 & & 1 & 0.4 & 4 & 0.6 \\
\hline Belonidae & 2 & 2.2 & 2 & 5.8 & 1 & 2.7 & 0 & & 0 & & 0 & & 0 & & 5 & 0.8 \\
\hline Lethrinidae & 1 & 1.1 & 0 & & 1 & 2.7 & 2 & 4.2 & 0 & & 6 & 5 & 2 & 0.8 & 12 & 1.9 \\
\hline Monotaxis sp. & 1 & & 0 & & 1 & & 2 & & 0 & & 2 & & 0 & & 6 & \\
\hline Lethrinus sp. & 0 & & 0 & & 0 & & 0 & & 0 & & 4 & & 2 & & 6 & \\
\hline Diodontidae & 0 & & 2 & 5.8 & 0 & & 0 & & 0 & & 0 & & 1 & 0.4 & 3 & 0.4 \\
\hline Muraenidae & 0 & & 0 & & 1 & 2.7 & 1 & 2.1 & 0 & & 0 & & 1 & 0.4 & 3 & 0.4 \\
\hline Mullidae & 0 & & 0 & & 0 & & 0 & & 0 & & 0 & & 2 & 0.8 & 2 & 0.3 \\
\hline Osteridae & 0 & & 0 & & 0 & & 0 & & 0 & & 0 & & 1 & 0.4 & 1 & 0.16 \\
\hline Coryphaenidae & 0 & & 0 & & 0 & & 0 & & 0 & & 1 & 0.8 & 0 & & 1 & 0.16 \\
\hline Mugilidae & 0 & & 0 & & 1 & 2.7 & 0 & & 0 & & 0 & & 0 & & 1 & 0.16 \\
\hline Tetradontiae & 0 & & 0 & & 1 & 2.7 & 0 & & 0 & & 0 & & 0 & & 1 & 0.16 \\
\hline sub-total & 75 & & 29 & & 30 & & 46 & & 72 & & 129 & & 219 & & 600 & 92.2 \\
\hline Erasmobranchii & MNI & $\%$ & MNI & $\%$ & MNI & $\%$ & MNI & $\%$ & MNI & $\%$ & MNI & $\%$ & MNI & $\%$ & MNI & $\%$ \\
\hline TypeA & 4 & 4.6 & 2 & 5.8 & 4 & 11.1 & 1 & 2.1 & 4 & 5.1 & 3 & 2.5 & 5 & 2.4 & 23 & 4.7 \\
\hline ТуреВ & 5 & 5.8 & 1 & 2.9 & 1 & 2.7 & 1 & 2.1 & 1 & 1.2 & 3 & 2.5 & 5 & 2.4 & 17 & 2.7 \\
\hline TypeC & 1 & 1.1 & 2 & 5.8 & 2 & 5.5 & 1 & 2.1 & 1 & 1.2 & 0 & & 0 & & 7 & 1.1 \\
\hline TypeD & 0 & & 0 & & 0 & & 0 & & 0 & & 1 & 0.8 & 0 & & 1 & 0.16 \\
\hline sub-total & 10 & 11.6 & 5 & 14.7 & 7 & 19.4 & 3 & 6.3 & 6 & 7.6 & 7 & 5.8 & 10 & 4.8 & 48 & 7.8 \\
\hline Total & 86 & & 34 & & 36 & & 47 & & 78 & & 119 & & 208 & & 608 & \\
\hline
\end{tabular}

Source: Table by the authors. 
Table 3. Identified fish remains from each unit* (NISP).

\begin{tabular}{|c|c|c|c|c|c|c|c|c|c|c|c|c|c|c|c|c|}
\hline TU & 1 & & 2 & & 3 & & 4 & & 6 & & 7 & & 8 & & Total & \\
\hline Bony fish & NISP & $\%$ & NISP & $\%$ & NISP & $\%$ & NISP & $\%$ & NISP & $\%$ & NISP & $\%$ & NISP & $\%$ & NISP & $\%$ \\
\hline Scaridae & 32 & 20.1 & 19 & 18.8 & 7 & 19.4 & 25 & 30.8 & 30 & 27 & 127 & 38.1 & 277 & 33.2 & 704 & 42.5 \\
\hline Scombridae & 53 & 33.3 & 64 & 63.3 & 3 & 8.3 & 16 & 19.7 & 21 & 18.9 & 51 & 15.3 & 120 & 14.3 & 501 & 30.2 \\
\hline Serranidae & 12 & 7.5 & 3 & 2.9 & 4 & 11.1 & 5 & 6.1 & 15 & 13.5 & 36 & 10.8 & 110 & 13.1 & 185 & 11.1 \\
\hline Carangidae & 3 & 1.8 & 0 & & 0 & & 5 & 6.1 & 3 & 2.7 & 26 & 7.8 & 66 & 7.9 & 103 & 6.2 \\
\hline Acanthuridae & 9 & 5.6 & 2 & 1.9 & 5 & 13.8 & 1 & 1.2 & 6 & 5.4 & 16 & 4.8 & 59 & 7 & 98 & 5.9 \\
\hline Balistidae & 6 & 3.6 & 1 & 0.9 & 1 & 2.7 & 10 & 12.3 & 15 & 13.5 & 22 & 6.6 & 28 & 3.3 & 83 & 5 \\
\hline Holocentridae (M) & 6 & 3.6 & 0 & & 2 & 5.5 & 4 & 4.9 & 4 & 3.6 & 11 & 3.3 & 36 & 4.3 & 63 & 3.8 \\
\hline Holocentridae (S) & 0 & & 0 & & & & & & 0 & & 9 & 2.7 & 27 & 3.2 & 36 & 2.1 \\
\hline Labridae & 1 & 0.6 & 0 & & 1 & 2.7 & 2 & 2.4 & 9 & 8.1 & 13 & 3.9 & 29 & 3.4 & 55 & 3.3 \\
\hline Siganidae & 1 & & 1 & & 0 & & 0 & & 1 & & 0 & & 23 & 2.7 & 26 & 1.5 \\
\hline Lutjanidae & 1 & & 0 & & 1 & & 1 & & 1 & & 2 & & 12 & 1.4 & 18 & 1 \\
\hline Sphyraenidae & 5 & 3.1 & 0 & & 0 & & 3 & 3.7 & 0 & & 0 & & 5 & 0.5 & 13 & 0.7 \\
\hline Belonidae & 8 & 5 & 2 & & 1 & & 0 & & 0 & & 0 & & 0 & & 11 & 0.6 \\
\hline Monotaxis & 1 & & 0 & & 1 & & 2 & & 0 & & 2 & & 2 & & 8 & 0.48 \\
\hline Lethrinus & 0 & & 0 & & 0 & & 0 & & 0 & & 4 & & 2 & & 6 & 0.36 \\
\hline Diodontidae & 0 & & 2 & & 0 & & 0 & & 0 & & 0 & & 1 & & 3 & 0.18 \\
\hline Muraenidae & 0 & & 0 & & 1 & & 1 & & 0 & & 0 & & 1 & & 3 & 0.18 \\
\hline Mullidae & 0 & & 0 & & 0 & & 0 & & 0 & & 0 & & 2 & & 2 & 0.12 \\
\hline Osteridae & 0 & & 0 & & 0 & & 0 & & 0 & & 0 & & 1 & & 1 & 0.06 \\
\hline Coryphaenidae & 0 & & 0 & & 0 & & 0 & & 0 & & 1 & & 0 & & 1 & 0.06 \\
\hline Mugilidae & 0 & & 0 & & 1 & & 0 & & 0 & & 0 & & 0 & & 1 & 0.06 \\
\hline Tetradontiae & 0 & & 0 & & 1 & & 0 & & 0 & & 0 & & 0 & & 1 & 0.06 \\
\hline sub-total & 138 & & 94 & & 29 & & 75 & & 105 & & 320 & & 801 & & 1562 & 94.4 \\
\hline Erasmobranchii & NISP & $\%$ & NISP & $\%$ & NISP & $\%$ & NISP & $\%$ & NISP & $\%$ & NISP & $\%$ & NISP & $\%$ & NISP & $\%$ \\
\hline TypeA & 9 & 5.6 & 4 & 3.9 & 4 & 11.1 & 3 & 3.7 & 4 & 3.6 & 3 & 0.9 & 20 & 2.3 & 47 & 2.8 \\
\hline ТуреВ & 10 & 6.2 & 1 & 0.9 & 1 & 2.7 & 1 & 1.2 & 1 & 0.9 & 9 & 2.7 & 13 & 1.5 & 36 & 2.1 \\
\hline TypeC & 2 & 1.2 & 2 & 1.8 & 2 & 5.5 & 2 & 2.4 & 1 & 0.9 & 0 & & 0 & & 9 & 0.5 \\
\hline TypeD & 0 & & 0 & & 0 & & 0 & & 0 & & 1 & 0.3 & 0 & & 1 & 0.06 \\
\hline sub-total & 21 & 13.2 & 7 & 6.9 & 7 & 19.4 & 6 & 7.4 & 6 & 5.4 & 13 & 3.9 & 33 & 3.9 & 93 & 5.6 \\
\hline Total & 159 & & 101 & & 36 & & 81 & & 111 & & 333 & & 834 & & 1655 & \\
\hline
\end{tabular}

Source: Table by the authors.

Table 4. Number of vertebra identified into taxa.

\begin{tabular}{lllllllll}
\hline TAXA/UNIT & TU8 & TU7 & TU6 & TU4 & TU3 & TU2 & TU1 & TOTAL \\
\hline Scombridae & 113 & 46 & 20 & 16 & 3 & 60 & 45 & 303 \\
Scaridae & 113 & 36 & 7 & 6 & 1 & 4 & 4 & 171 \\
Sharks & 38 & 21 & 9 & 5 & 4 & 7 & 22 & 106 \\
Siganidae & 17 & 0 & 0 & 0 & 0 & 1 & 3 & 21 \\
Carangidae & 5 & 1 & 0 & 6 & 0 & 0 & 5 & 17 \\
Belonidae & 0 & 0 & 0 & 0 & 1 & 0 & 9 & 10 \\
Sphyraenidae & 1 & 0 & 0 & 2 & 0 & 0 & 0 & 3 \\
Muraenidae & 1 & 0 & 0 & 0 & 1 & 0 & 0 & 2 \\
Serranidae & 0 & 1 & 0 & 0 & 0 & 0 & 0 & 1 \\
Balistidae & 1 & 0 & 0 & 0 & 0 & 0 & 0 & 1 \\
\hline
\end{tabular}

Source: Table by the authors.

Concerning the spatial distribution of fish remains on the islet, TU 1 to 6 were located in the northern part of the village and produced about 100 NISP of the total identified fish bones in each unit, while TU 7 and 8 were located in the southern part of the village and produced 300 to 800 NISP of the total identified fish bones (see Table 3). The result tentatively indicates that the intensive use and discard of fish (bones) was done around TU 7 and 8. As described above, TU 
4 and 6 produced some human remains including skulls and they were possibly part of a mainly burial area on the islet, while no human remains except teeth were found in TU 1, 2, 3, 7 and 8 and thus these units might be part of a mainly habitation area.

In relation to each fish taxa and excavation unit, a high abundance of Scombrids (about 14-35\% of the total MNI) is confirmed in TU 1, 2, 4, and 6, while the relative abundance of Scombrids is lower in TU 3, 7, and 8. Similarly, the relative abundance of Balistids and Acanthurids also show differences between each unit. The relative abundance of Balistids is higher in TU 4, 6, and 7 (16-21\%), while lower in TU 1, 2, and 8 (2.9-7.9\%). On the other hand, the relative abundance of Acanthurids is higher in TU 1, 3, 7 (10-13\%), and particularly in TU 8 (27.8\%). It is yet uncertain why so many Acanthurid bones ( $n=58$ ) were concentrated at TU 8 while TU 7, which is located next to TU 8, did not produce as many $(\mathrm{n}=16)$. Other major fish taxa such as Scarids and Serranids are generally high in all units, except Serranids in TU 2 whose relative abundance is a bit lower (5.8\%).

In terms of temporal change in fish use, we only have ${ }^{14} \mathrm{C}$ dates from TU 1 and 7 (see 3.3). These ${ }^{14} \mathrm{C}$ dates indicate the lower layer of TU 1 dated to $-600 \mathrm{cal}$ BP, while TU 7 and possibly TU 8 might have been formed at $-200 \mathrm{cal}$ BP. As shown in Table 5, a higher abundance of inshore fish species is the trend in TU 7 and 8 while TU 1, which currently has the oldest date from a reliable context on Atafu, contains a higher abundance of pelagic species such as Scombrids (Table 5). If this result is not an effect of differential spatial patterns in site use, there is a possibility that more intensive inshore use was practised during the later times on Atafu. On the other hand, the relative abundance of Scombrids and Scarids are both high in the lower layers at TU 1, and their abundances are continually high in the middle-to-upper layers (see Table 5). Although no ${ }^{14} \mathrm{C}$ dates were processed from the middle-to-upper layers and hence we do not know the exact dates of these layers, the results of the fish assemblage in TU 1 tentatively indicates that Scombrids and Scarids were the most important fish family in Atafu's prehistory, dating back $-600 \mathrm{cal}$ BP.

Table 5. Identified fish taxa in spit level at TU1.

\begin{tabular}{lllllllllllllll}
\hline TAXA/SPIT & $\mathbf{1}$ & $\mathbf{2}$ & $\mathbf{3}$ & $\mathbf{4}$ & $\mathbf{5}$ & $\mathbf{6}$ & $\mathbf{7}$ & $\mathbf{8}$ & $\mathbf{9}$ & $\mathbf{1 0}$ & $\mathbf{1 1}$ & $\mathbf{1 2}$ & $\mathbf{1 3}$ & TOTAL \\
\hline Scombridae & 3 & 0 & 1 & 2 & 1 & 1 & 0 & 4 & 1 & 0 & 3 & 2 & 2 & 20 \\
Scaridae & 1 & 2 & 0 & 1 & 1 & 1 & 0 & 2 & 1 & 2 & 2 & 1 & 2 & 16 \\
Serranidae & 0 & 1 & 2 & 0 & 0 & 1 & 0 & 1 & 0 & 1 & 2 & 0 & 1 & 9 \\
Acanthuridae & 4 & 0 & 0 & 0 & 0 & 2 & 0 & 1 & 1 & 0 & 0 & 0 & 1 & 9 \\
Balistidae & 1 & 1 & 0 & 0 & 0 & 0 & 0 & 0 & 0 & 2 & 1 & 0 & 1 & 6 \\
Holocentridae & 1 & 2 & 0 & 0 & 0 & 0 & 0 & 0 & 0 & 0 & 0 & 0 & 1 & 4 \\
Carangidae & 0 & 2 & 0 & 0 & 0 & 0 & 0 & 1 & 0 & 0 & 0 & 0 & 0 & 3 \\
Lethrinidae & 0 & 0 & 0 & 0 & 0 & 0 & 0 & 1 & 0 & 0 & 0 & 1 & 0 & 2 \\
Belonidae & & & 1 & 0 & & 0 & & 0 & & 1 & 0 & 0 & 0 & 2 \\
Lutjanidae & 0 & 0 & 0 & 1 & 0 & 0 & 0 & 0 & 0 & 0 & 0 & 0 & 0 & 1 \\
Labridae & 0 & 0 & 0 & 0 & 0 & 0 & 0 & 0 & 0 & 1 & 0 & 0 & 0 & 1 \\
Spyraenidae & & & & 1 & & 0 & & 0 & & 0 & 0 & 0 & 0 & 1 \\
Monotaxis sp. & 0 & 0 & 0 & 0 & 0 & 0 & 0 & 0 & 0 & 0 & 0 & 0 & 1 & 1 \\
Siganidae & 0 & 1 & 0 & 0 & 0 & 0 & 0 & 0 & 0 & 0 & 0 & 0 & 0 & 1 \\
\hline sub-total & 10 & 9 & 4 & 5 & 2 & 5 & 0 & 10 & 3 & 7 & 8 & 4 & 9 & 76 \\
\hline SharkA & 0 & 1 & 0 & 0 & 0 & 0 & 0 & 1 & 1 & 0 & 0 & 0 & 1 & 4 \\
SharkB & 1 & 1 & 0 & 0 & 0 & 1 & 0 & 0 & 0 & 1 & 0 & 0 & 1 & 5 \\
SharkC & 0 & 0 & 0 & 1 & 0 & 0 & 0 & 0 & 0 & 0 & 0 & 0 & 0 & 1 \\
\hline sub-total & 1 & 2 & 0 & 1 & 0 & 1 & 0 & 1 & 1 & 1 & 0 & 0 & 2 & 10 \\
\hline Total & 11 & 11 & 4 & 6 & 2 & 6 & 0 & 11 & 4 & 8 & 8 & 4 & 11 & 86 \\
\hline
\end{tabular}

Source: Table by the authors. 


\section{Discussion and Conclusion}

The amount of fish remains excavated from Atafu clearly indicate that marine fish, both inside and outside of the lagoon, was one of the most important subsistence activities since the early settlement period, which may date to $-600 \mathrm{cal} \mathrm{BP}$. Since no archaeological data of prehistoric fishing or fish use on Atafu were provided by previous studies, these data are the only light currently shed on prehistoric fish use on Atafu.

Our current analysis of Atafu fish remains clearly indicates that various marine fish taxa, both inshore and offshore species, were exploited in the past on Atafu. Particularly, the number and relative abundance (MNI) of Scombrids and Scarids were highest among these taxa. The abundance of Scombrid bones in our recent excavations on Atafu shows a clear contrast with the results of the past studies on Fakaofo by Best (1988) and McAlister (2002), which could identify only a few Scombrid bones. Neglect of vertebra for the identification seems to be the possible major factor for such difference between our result and those of past studies, and thus we strongly recommend using more elements, including vertebra for fish identification in future studies. For instance, vertebra are also useful to identify Elasmobranchii, Carangids, Muraenids, Belonids, Siganids, and Scarids (see also Ono and Intoh 2011), while palatine is useful to identify Serranids and Lethnrinus sp. Thus, using more elements for fish bone identification may increase the variety of fish taxa and relative abundance of each taxon at each site.

On the other hand, the high number and relative abundance of Scombrids among some units, particularly TU 1 which dated back to $-600 \mathrm{cal} \mathrm{BP}$, tentatively indicates that offshore fish species were important marine resources since the earliest currently known human presence on Atafu. The high number and relative abundance of Carangids, Serranids, Holocentrids, and sharks also indicate such a possibility. Although these fish taxa are also captured within inshore and lagoon zones, our ethno-ecological study of contemporary fishing by Atafu people (Ono and Addison 2009) and other research on Tokelau fishing (Gillett 1985; Hooper 1985, 2008, 2010; Mafutagaa-Toeania-o-Atafu-i-Matauala-Porirua 2008) show that these taxa are usually captured in the outer-reef to pelagic zones by angling or lure fishing.

Our ethno-ecological study also reveals that there are more variations in names and fishing methods for larger pelagic fish species such as Scombrids and Caranginds (Ono and Addison 2009), and thus we suggest that a high dependence on offshore marine resources has been one of the prominent characteristics of Atafu fishing from the early human colonisation to the present.

The limited amount of molluscan remains in our excavations and the limited number of mollusc names on contemporary Atafu (Ono and Addison 2009:16) indicate the relative scarcity of shellfish resources on Atafu with its small-sized lagoon and limited reef area around the atoll. These biogeographical constraints of Atafu might be a major factor in the apparent long-term high dependence of its human population on offshore resources. Although the detailed analysis of the molluscsan remains excavated by our research is still in progress, initial examination suggests that most of them are occupied by species of the genera Tridacna and Turbo.

As for inshore fish exploitation, however, our archaeological analysis of fish remains reveals that a variety of inshore fish species have also been exploited since the ancient past. Particularly, MNI and relative abundance of Scarids, Acanthurids, and Balistids were the highest among the inshore fish identified. Our ethno-ecological study of fish names on Atafu also confirms the relative higher variety of individual names in these fish family. For instance, Scarids ( $u f u$ ) have 20 different individual fish names, while Acanthurids (ume) have 14 names and Balistids (bumu) have 7 names (Ono and Addison 2009:21-22). 
Other ethno-archaeological or ethno-ecological studies on contemporary fishing in the Pacific and Southeast Asia (e.g., Kirch and Dye 1979; Masse 1989; Ono 2007, 2009, 2010; Ono and Addison 2009; Rolett 1989; Wright and Richard 1985) as well as Butler's (1994) zoo-archaeological study focusing on fish feeding behaviour and fish capture, clearly indicate that the most suitable method to capture slow swimming herbivorous fish with a small mouth such as Scarids, Acanthurids and Balstids is netting and spearing, while the method to capture fast swimming or bottom dwelling carnivorous fish with a large mouth such as those belonging to Serranids, Lutjanids, Labrids, Scombrids, Holocentrids and sharks is angling. Trolling-lure fishing is another major method to capture fast-swimming pelagic fish such as Scombrids and Sphyraenids. Some fish families such as Lethrinids and Carangids are mainly captured by both netting and angling, while some certain species such as Monotaxis sp. (sea bream) or larger species are more frequently caught by angling.

When we apply such ethno-ecological or ethno-archaeological fishing data for archaeological reconstruction based on the excavated fish species, the reconstructed possible major fishing methods during the early colonisation time on Atafu were both netting and angling, with the possible use of spearing and other methods. The high relative abundance (\%MNI) of Scombrids also indicates the possible use of trolling in the pelagic zone from this early period. Although the associated dates are unclear, the previous excavations by Best found numbers of fish hooks and lures including a complete pearl-shell lure (Best 1988:110; McAlister 2002:48). Such archaeological evidence also indicates intensive use of angling and trolling in prehistoric Tokelau, including Atafu. On the other hand, the relatively large number of Holocentrids among the excavation units on Atafu indicates the possible use of small-sized fish hooks and lures to capture these smaller-sized fish species. In fact, the previous excavations by Best found five pieces of worked shell that resembled the small lures used today in Tokelau for catching Holocentrids (McAlister 2002:48).

All the evidence we have discussed here tentatively indicates that the prehistoric populations on Atafu, unsurprisingly, arrived with developed fishing techniques, particularly for outer-reef to pelagic zone fishing such as angling and trolling. The existence of a number of shark and sea turtle bones from the lower excavation layers also indicates that the people have continually captured these larger-sized offshore marine species as well. It should be noted, however, that the people also targeted inshore species inhabiting the lagoon to fringing reef zones and such trends of fish use in the past seem very similar to what Atafu's fishers practice today.

Based on current information, the only exceptions we note are the exploitation of flying fish and marlins, whose bones are not yet identified from the fish bone assemblages we analysed, although both taxa are highly important in traditional and contemporary fishing in Tokelau, including Atafu (e.g., Mafutaga-a-Toeania-o-Atafu-i-Matauala-Porirua 2008; Matagi Tokelau 1991). Regarding flying fish exploitation, however, there is a possibility to find and identify them when we analyse all the small fish bones sieved by $1 / 8$ inch screen, as most flying fish bones are relatively smaller and hard to find when sieving by $1 / 2$ or $1 / 4$ inch screens. On the other hand, marlin bones are usually much larger, though this fish species might be rarely captured; we did not observe Atafu fishers capture this species during our stays. Also, marlins are regarded as one of the sacred fish and its meat should be equally distributed to all the households on the island, even today. If marlin species were rarely captured in the past as well, it will be harder to find their bones in small-sized test units and larger areal excavations will be required to find them in future research.

In terms of tradiational marine-conservation measures on Atafu, we should mention again the inati system of distribution, which is currently practised on all atolls in Tokelau. As described above, all resident members of the village are assigned to an inati group and certain types of 
marine food, including sea turtles, schools of skipjack tunas and marlins are considered as ika $h a$ (sacred fish) to be shared among the village when they are caught. Although we do not know when such a system of distribution was started in Tokelau, it might be a long-time tradition (at least over a few hundred years) since all the atolls maintain the same system and it is well-known ethnographically.

It should also be noted that the ika ha that are always shared by the whole community are all offshore species. A possible reason for this might be because these species could be captured only rarely or seasonally, such as sea turtles which can only be captured during October to March. The recent drop of skipjack tunas from the $i k a ~ h a$ category also supports this possibility, because modern fishing gear and boats have made skipjack tunas relatively easier to capture. However, it is also quite obvious that skipjack tunas were culturally and socially a very significant fish species (see Hooper 1985, 1991, 2008, 2010; Hooper and Huntsman 1991). Our analysis of the excavated fish bones also confirms that Scombrids, including skipjack tunas, were one of the major and important protein sources in prehistoric times. Such cultural and social significance can be another major reason why these species have been regarded as ika ha.

On the other hand, it is also true that the inati system does not directly work on marine conservation since there is no control of the amount and number of capture. It is possibly because all the fish or animals regarded as ika ha are offshore species, and thus it is not necessary to control their capture since their capture is naturally controlled by luck or seasonal effects, etc. In considering marine conservation measures in small island ecosystem such as on atolls, measures to control inshore fish capture become more important.

In this regard, Atafu and other atolls in Tokelau have the lafu system, which is the periodic imposing of use-restrictions on specific areas of the reef by the taupulega, or the island ruling council (Toloa et al. 1994). As described above, most of the reef fronting the village on Atafu is restricted from private fishing, and only communal fishing (faiva fakamua) is allowed at certain times of the year. It is also important that all the catch (mainly inshore fish species) by such communal fishing is shared and distributed by the inati system. In this way, the inati and lafu system are connected together as the major marine conservation measure in Tokelau, especially in regard to limited resources, such as inshore fish on Tokelau. Although, as in the case of the inati system, we do not know when the lafu system was started in Tokelau, our preliminary reconstruction of a well-balanced exploitation of both inshore and offshore fish species in Atafu's past tentatively indicates that marine conservation measures have played an important part in marine resource exploitation since prehistoric times.

Lastly, concerning mesh-size effects on the recovery of fish bones, Butler (1994:85) noted relative fish family abundance was similar across screen mesh fractions $(3 \mathrm{~mm}, 5 \mathrm{~mm}$, and $7 \mathrm{~mm}$ in her case) based on material excavated from Manus in the Bismarck Archipelago, and indicates that mesh size did not skew the recovery of remains of fish taxa of particular sizes in the assemblages were considered. However, it is generally accepted that mesh size does affect results of faunal analysis (Thomas 1969), particularly for fish bone analysis (e.g., Casteel 1972; Nagaoka 2005; Wheeler and Jones 1989). An initial examination of our Atafu material collected by $1 / 8$ inch size mesh suggests that the total number of fish bones, particularly of smaller-bodied species, will be dramatically increased when we finish their analysis.

Although our analysis of fish remains sieved by $1 / 8$ inch size mesh is under progress, we would like to stress the importance of employing fine mesh (with $1 / 8$ inch at minimum) screening (see also Ono 2010; Ono and Clark 2010; Reitz et al. 2009:17) as well as increasing the variety 
of elements analysed in order to recover and identify as many faunal remains (particularly fish bones) as possible. Once this type of analysis is conducted on fish bone assemblages, we should be able to reconstruct the past changes of fish exploitation and fishing strategies in greater detail.

Our study in Tokelau has just started, and it is now required to extend our ethno-ecological and archaeological investigations not only on Atafu but also on the other atolls of Tokelau including Nukunonu and Fakaofo so that we can compare characteristics and trends in past and present marine resource use, fishing lore, material culture and the social aspects related to marine use. Once this is done, we can begin to infer how each different atoll environment affected fish and marine use on each atoll and also to consider future use and conservation measures on marine resources in Tokelau and also other islands in Indo-Pacific region.

\section{Acknowledgements}

We wish to express our appreciation to the people of Atafu, particularly for their warm friendship and support of our research and hospitality during our stays on their atoll. Although it is impossible to name each individually here, we wish to thank all of our friends in Atafu. This work would not have been possible without the active support the Atafu Taupulega, the Fatupaepae, and the Aumaga, which were each helpful, engaged, and profoundly interested in helping to understand their atoll's past. All the government offices on Atafu extended the hospitality and assistance to us, especially. The crew of the MV Tokelau has always been generous, kind, and accommodating. Staff at the Tokelau Office in Apia have also been of great help and assistance on many occasions. We also have special thanks to David \& Gail Funk, and Ann \& Barry Lange for their kind help and volunteering to take us to Atafu with their sail boats. Without their help and kindness, we could not have conducted our 2008 season research in Atafu. The 2008 research was carried out as a part of the "Tokelau Science Project" funded in part by the University of South Pacific and Tokelau government. The Tokelau Science project is truly a collaboration between Tokelau communities and outside people. We offer this paper as a small and humble contribution to this collaboration. All mistakes and faults in fact and interpretation remain ours.

\section{References}

Addison D.J. and T.S. Asaua. 2006. 100 new dates from Tutuila and Manu'a: Additional data addressing chronological issues in Samoan prehistory. Journal of Samoan Studies 2:95-117.

Addison D.J. and J. Kalolo. 2009. Tokelau Science Education and Research Program: Atafu fieldwork August 2008. Pago Pago and Atafu: Samoan Studies Institute and Tokelau Department of Education.

Addison D.J., B. Bass, C.C. Christensen, J. Kalolo, S.P. Lundblad, P.R. Mills, F. Petchey, and A. Thompson. 2009. Archaeology of Atafu, Tokelau: Some initial results from 2008. Rapa Nui Journal 23(1):5-9.

Best, S.B. 1988. Tokelau archaeology: A preliminary report of an initial survey and excavations. Bulletin of the Indo-Pacific Prehistory Association 8:104-18.

Best, S.B., P.J. Sheppard, R.C. Green, and R.J. Parker. 1992. Necromancing the stone: Archaeologists and adzes in Samoa. Journal of the Polynesian Society 101(1):45-85.

Buck, P. (Te Rangi Hiroa). 1930. Samoan material culture. Honolulu: Bishop Museum Press. Bernice P. Bishop MuseumBulletin 75.

Burrows, E.G. 1939. Western Polynesia: A study in cultural differentiation. Gothenburg: Ethnological Studies 7. 
Burrows, E.G. 1940. Culture-areas in Polynesia. Journal of the Polynesian Society 49(195):349-66.

Butler, V.L. 1994. Fish feeding behaviour and fish capture: The case for variation in Lapita fishing strategies. Archaeology in Oceania 29:81-89.

Campos, F.Z. 2009. The Ichthyoarchaeology of Batanes Islands, Northern Philippines. Unpublished master's thesis, Department of Archaeology, University of Philippines.

Casteel, R.W. 1972. Some biases in the recovery of archaeological faunal remains. Proceedings of the Prehistoric Society 36:382-388.

Chaplin, R.E. 1971. The Study of Animal Bones from Archaeological Sites. London: Seminer Press.

Davidson, J.M., K. Fraser, B.F. Leach, and Y.H. Sinoto. 1999. Prehistoric fishing at Hane, Ua Huka, Marquesas Islands, French Polynesia. New Zealand Journal of Archaeology 21:5-28.

Froese, R. and Pauly D. (eds). 2009. Fish-Base. World Wide Web electronic publication, available at http://www.fishbase.org/

Gillett, R.D. 1985. Traditional tuna fishing in Tokelau. Noumea: South Pacific Commission. South Pacific Regional Environmental Programme Topic Review 27.

Green, R.C. 1966. Linguistic subgrouping within Polynesia: The implication for prehistoric settlement. Journal of the Polynesian Society 75:6-38.

Green, R.C. 1988. Subgrouping of the Rapanui language of Easter Island in Polynesia and its implications for east Polynesian prehistory. In C.F. Cristino, P.C. Vargas, R.S. Izaurieta, and R.P. Budd (eds), First International Congress, Easter Island and East Polynesia 1, pp. 37-58. Santiago: University of Chile.

Hale, H. 1846. United States Exploring Expedition. Ethnography and philology. Philadelphia: Lee and Blanchard.

Hooper, A. 1985. Tokelau fishing in traditional and modern contexts. In R.E. Johannes and K. Ruddle (eds), Traditional knowledge and management of coastal systems in Asia and the Pacific, pp. 7-38. Jakarta: UNESCO.

Hooper, A. 1991. Aspects of skipjack fishing: Some Tokelau words of the sea. In A.K. Pawley (ed), Man and a half: Essays in Pacific anthropology and ethnobiology in honour of Ralph Bulmer, pp. 249-256. Auckland: The Polynesian Society.

Hooper, A. 2008. Old men and the sea. In C. Sather and T. Kaartinen (eds), Beyond the horizon: Essays on myth, history, travel and society, pp. 91-100. Helsinki: The Finnish Literature Society.

Hooper, A. 2010. Two Tokelau fishing texts. Journal of the Polynesian Society 119 (3):227-268.

Hooper, A. and J. Huntsman (eds). 1991. Matagi Tokelau. History and traditions of Tokelau. Apia and Suva: Office for Tokelau Affairs and University of the South Pacific.

Hooper. R. 1994. Reconstructing proto Polynesian fish names. In A.K. Pawley and M. Ross (eds), Austronesian terminologies: Continuity and change, pp. 185-229. Canberra: Department of Linguistics, The Australian National University. Pacific Linguistics Series C-127.

Huntsman, J. and A. Hooper. 1996. Tokelau: A historical ethnography. Auckland: Auckland University Press.

Johannes, R.E. 1981. Words of the Lagoon: Fishing and marine lore in the Palau district of Micronesia. Berkeley: University of California Press.

Kirch P.V. 1997. The Lapita peoples: Ancestors of the oceanic world. Oxford: Blackwell Publishers. 
Kirch P.V. and T.S. Dye. 1979. Ethno-archaeology and the development of Polynesian fishing strategies. Journal of the Polynesian Society 88:53-76.

Kirch, P.V. and R.C. Green. 2001. Hawaiki: Ancestral Polynesia. Cambridge: Cambridge University Press.

Leach, B.F. 1986. A method for analysis of Pacific island fishbone assemblages and an associated data base management system. Journal of Archaeological Science 13(2):147-159.

Leach, B.F., J.M. Davidson, M. Horwood, and P. Ottino. 1997. The fishermen of Anapua Rock Shelter, Ua Pou, Marquesas Islands. Asian Perspectives 36(1):51-66.

Leach, B.F. and J.M. Davidson. 1977. Fishing methods and seasonality at Paremata (N160/50). New Zealand Archaeological Association Newsletter 20(3):166-175.

Macgregor, G. 1937. Ethnology of Tokelau Islands. Honolulu: Bishop Museum Press. Bernice P. Bishop Museum Bulletin 146.

Mafutaga a Toeaina o Atafu i Matauala Porirua. 2008. Hikuleo: I te Papa o Tautai. Wellington: Steele Roberts Ltd.

Marck, J. 2000. Topics in Polynesian language and culture history. Canberra: Pacific Linguistics, Research School of Pacific and Asian Studies, The Australian National University.

Masse, W.B. 1986. A millenium of fishing in the Palau Islands, Micronesia. In A. Anderson (ed), Traditional fishing in the Pacific: Ethnographic and archaeological papers from the 15th Pacific Science Congress, pp. 85-117. Honolulu: Bishop Museum Press.

Masse, W.B. 1989. The archaeology and ecology of fishing in the Belau Islands, Micronesia. Unpublished doctoral dissertation. Department of Anthropology, Southern Illinois University.

Matagi Tokelau. 1991. Matagi Tokelau: History and traditions of Tokelau. Apia and Suva: Office of Tokelau Affairs and the Institute of Pacific Studies, University of the South Pacific.

McAlister, A.J. 2002. Prehistoric fishing at Fakaofo, Tokelau: A case for resource depression on a small atoll. Unpublished master's thesis. Department of Anthropology, University of Auckland.

Nagaoka, L. 2005. Differential recovery of Pacific Island fish remains. Journal of Archaeological Science 32:941-955.

Statistics New Zealand. 2001. New Zealand Census 2001.

Ono, R. 2003. Prehistoric Austronesian fishing strategies: A tentative comparison between Island Southeast Asia and Lapita Cultural Complex. In C. Sand (ed), Pacific Archaeology: assessments and prospects, pp. 191-201. Noumea: New Caledonia Museum.

Ono, R. 2004. Prehistoric fishing at Bukit Tengkorak rock shelter, east coast of Borneo Island. New Zealand Journal of Archaeology 24:77-106.

Ono, R. 2006. Marine Exploitation and Subsistent Strategies in Celebes Sea: An Ethnoarchaeological Studies to Area Studies. Unpublished doctoral thesis, University of Sophia, Tokyo. (in Japanese).

Ono, R. 2007. Tradition and modernity in fishing among the Sama, eastern coast of Borneo, Malaysia. Bulletin of the National Museum of Ethnology 31(4):497-579 (in Japanese).

Ono, R. 2009. Ethnoarchaeology in coral seas. Quarterly of Archaeological Studies 55(4):75-94 (in Japanese).

Ono, R. 2010. Ethnoarchaeology and the early Austronesian fishing strategies in near-shore environments. Journal of the Polynesian Society 119(3):269-314. 
Ono, R. and D. Addison. 2009. Ethnoecology and Tokelauan fishing lore from Atafu atoll, Tokelau. SPC Traditional Marine Resource Management and Knowledge Information Bulletin 26:3-22.

Ono, R. and M. Intoh. 2011. Island of pelagic fishermen: Temporal change in prehistoric fishing on Fais, Micronesia. Journal of Island and Coastal Archaeology 6:255-286.

Passfield, K. 1998. A report of a survey of the marine resources of Fakaofo Atoll, Tokelau. Fisheries and Environmental Resource Consultants Ltd., available at http://www.spc.int/coastfish/ Countries/ Tokelau/Fakaofofishery.pdf

Pawley, A. 1966. Polynesian languages: A subgrouping on shared innovations in morphology. Journal of the Polynesian Society 75:39-64.

Pawley, A. 1967. The relationships of the Polynesian outliers languages. Journal of the Polynesian Society 76:259-296.

Petchey, F., D.J. Addison, and A.J. McAlister. 2010. Re-interpreting old dates: Radiocarbon determinations from the Tokelau Islands (South Pacific). Journal of Pacific Archaeology 1(2):161-167.

Rensch, K. 1994. Fish names of Western Polynesia. Canberra: Archipelago Press.

Reitz, E.J., I.R. Quitmyer, and R.A. Marrinan. 2009. What are we measuring in the zooarchaeological record of prehispanic fishing strategies in the Georgia Bight, USA? Journal of Island and Coastal Archaeology 4(1):2-36.

Rolett, B.V. 1998. Hanamiai: Prehistoric colonization and cultural change in the Marquesas Islands, East Polynesia. New Haven: Department of Anthropology and The Peabody Museum Yale University. Yale University Publications in Anthropology No. 81.

Tokelau Dictionary. 1986. Tokelau Dictionary. Apia: Office of Tokelau Affairs.

Toloa F., M. Pelasio, and R.D. Gillett. 1994. Adapting traditional marine conservation in Tokelau. In R.J. Morrison, P.A. Geraghty, and L. Crowl (eds), Science of Pacific Island peoples Vol. 1, pp. 121127. Suva: Institute of Pacific Studies, University of the South Pacific.

Thomas, D.H. 1969. Great Basin hunting patterns: a quantitative method for treating faunal remains. American Antiquity 34:393-401.

Toizumi, T. 2007. Analytical problems with identification of fish remains in prehistoric Ryukyu: influences from differences in screening methods and identified elements used in analysis. In M. Marui (ed), Archaeological Studies on the Cultural Diversity in Southeast Asia and Its Neighbors, pp. 307-20. Tokyo: Yuzankaku Press. (in Japanese).

Vogel, Y. 2005. Ika. Unpublished master's thesis, Department of Anthropology, University of Otago.

Whistler, W.A. 1988. Ethnobotany of Tokelau: The plants, their Tokelau names, and their uses. Economic Botany 42(2):155-176. 